\title{
An investigation into retrofitting the pre-1919 owner-occupied UK housing stock to reduce carbon emissions
}

\begin{abstract}
In the UK, housing has been identified as a significant sector for contributing to the $80 \%$ reduction in emissions over the 1990 baseline by 2050, required by the Climate Change Act of 2008. However, pre1919 housing stock is the least energy efficient and consequently poses challenges to meeting this target. Using a mixed methods approach, the current study demonstrates that, in actuality, there is a significant potential for reducing emissions among this sub-sector of housing, and that the major barriers to energy efficiency retrofits concern a lack of funding, the payback period for the investment, disruption to home life and finding a trustworthy and skilled installer. Moreover, this study finds that homeowners are motivated primarily by the desire to improve home comfort and aesthetics along with a reduction in energy bills rather than in reducing carbon emissions. The paper concludes with recommendations for improving the viability of retrofitting pre-1919 homes through enhanced financial resources, policy support and the promotion of social and economic benefits.
\end{abstract}

Key words: Retrofitting, pre-1919 housing stock, carbon emissions, homeowners, viability

\section{Introduction}

The UK government has been making efforts to reduce energy consumption and carbon emissions since the early 1970s when the oil crisis presented severe energy supply concerns (Shorrock, 2003). In 1979, the Geneva World Climate Conference highlighted the adverse impacts of human activities on climate due to increasing carbon emissions (UNFCCC, 2014). Of these activities, the domestic housing sector has potential for reducing the energy consumption and carbon emissions, which have led to the introduction of heat loss standards for new homes in UK building regulations (Dowson et al., 2012). In 2008, the UK government passed its first Climate Change Act for an $80 \%$ reduction in carbon emissions by 2050 as per the 1990 baseline, with an intermediate target of $34 \%$ set for 2020 (HMSO, 2008; DECC, 2015a). This offers an overarching policy landscape for all sectors to reduce carbon emissions. It also led the UK government's Chief Construction Advisor to state: "we are going to need to start counting carbon as rigorously as we count money" (Richardson, 2009). The UK government views housing as a primary sector to tackle carbon emissions, believing that retrofitting the existing domestic stock is the most cost effective and technically appropriate method for reducing emissions (Hamilton et al., 2013).

At present, the number of retrofits being undertaken is below the required level to meet the national carbon reduction targets (Fawcett, 2014) with only $2.9 \%$ to $5 \%$ of existing housing retrofitted annually (Eames et al., 2013). This needs to be increased and thousands of retrofits are required each year 
(Fawcett, 2014). Gleeson et al. (2011) suggest that a retrofit rate of "1 house per minute till 2050" is required to meet the government's targets, along with £200bn-£400bn in investment (Technology Strategy Board, 2013). 20\% of the existing housing stock in the UK consists of pre-1919 homes (DCLG, 2015a), which is the least energy efficient but also has the greatest potential for energy and carbon savings (Power, 2008). In exploring the economic, social, technical and legal drivers and barriers to retrofitting the domestic building sector, this paper first reviews the need for sustainable retrofitting including energy consumption and carbon emissions in domestic buildings. Following this review, the methods applied in the study are discussed and data analysis and results presented. The paper concludes by considering the key findings and offers recommendations to promote the retrofit policy agenda.

\section{Sustainable Retrofitting of Pre-1919 Housing Stock}

This section begins by presenting the case for retrofitting the UK's pre-1919 housing stock to reduce carbon emissions. First, the current rate of emissions in domestic buildings is considered followed by a review of the available opportunities for sustainable retrofits.

\subsection{Carbon emissions in domestic buildings}

In 2013, residential buildings were the second largest contributor to carbon emissions in the UK, accounting for $139.9 \mathrm{MtCO}_{2} \mathrm{e}$ and representing a potential $18.8 \%$ carbon emissions reduction against the 1990 baseline (DECC, 2015a), although a significant percentage of this is attributed to decarbonisation of the fuel supply (Lomas, 2010). In the building life cycle, carbon emissions can be in two forms, namely: embodied and operational carbon (UKGBC, 2015 and Ibn-Mohammed et al., 2013). Although there are no regulations that govern embodied carbon emissions in buildings, policy continues to address carbon emissions generated through a building's operational energy consumption (Iddon and Firth, 2013). Even if operational carbon is the more pressing concern, IbnMohammed et al. (2013) report that proposed decarbonisation of the energy supply by 2030 could result in embodied carbon becoming more significant.

Pre-1919 housing stock's operational carbon emissions are estimated at $86 \mathrm{kgCO}_{2} / \mathrm{m}^{2} /$ year (Moran et al., 2014), with average annual emissions of $9.4 \mathrm{tCO}_{2} \mathrm{e}$ compared to $1.5 \mathrm{tCO}_{2} \mathrm{e}$ in newer housing stock (Atkins and Emmanuel, 2014; DCLG, 2015b). Fawcett et al. (2010) state that whole house retrofit is required within the existing UK housing stock to achieve the desired reduction in carbon emissions. Furthermore, technical improvements have the potential to offer a $40 \%$ reduction in emissions, while $20 \%$ of all buildings' carbon emissions can be addressed through insulation to increase the thermal performance (MacKenzie et al., 2010).

As Crilly et al. (2012) argue, a purely technical approach is inadequate. Instead, an integrated and comprehensive understanding of the retrofit process is essential in order to make informed decisions 
on the energy efficiency of homes. Previous research suggests that housing stock represented $29 \%$ of the UK's energy demand, consuming 502 TWh (Palmer and Cooper, 2013), with an average 2014 household consuming 18,600 kWh per annum, of which space heating accounted for approximately $60 \%$ (Jones et al, 2013; Hamilton et al. 2013). As Bernier et al. (2010) argue, this is because the UK housing stock is the oldest and least efficient in Europe, demanding twice the space heating of Nordic dwellings, even after climate adjustments (Boardman, 2007a). More significantly, the pre-1919 solid wall housing stock demands $14000 \mathrm{kWh}$ per year, more than twice that of post 2010 housing (6300 kWh) in heating alone (Moorhouse and Littlewood, 2013).

The assessment of energy use in UK dwellings is primarily undertaken by using the Standard Assessment Procedure (SAP), which evaluates the energy use arising from space heating, water heating, ventilation and lighting, deducting energy generation from renewable technologies (BRE, 2014). Under the EU Energy Performance of Buildings Directive (EPBD), it is a legal requirement for the SAP score to be displayed on the dwellings' Energy Performance Certificate (EPC) (Griffiths, 2010). When the SAP was introduced in 1970, the average rating of the UK homes was 17.6, this has since substantially increased to 60 in 2013. This is largely due to the uptake of more energy efficient appliances and heating systems in addition to new homes being constructed from more effective building fabric (Hamilton et al., 2013; DCLG, 2015a). DECC (2015b) confirms that newer homes have significantly higher SAP rating than pre-1919 homes in the UK, and Ding (2013) suggests that green construction is now becoming more common practice for modern housing stock. While Boardman (2007a) argues that the existing housing stock is the greatest challenge in the UK when it comes to reducing energy consumption, Plimmer et al. (2008) and Baeli (2013) suggest that older homes can improve thermal performance through retrofit measures such as, insulation, glazing and draught proofing, which can help reduce energy and carbon emissions.

\subsection{Sustainable retrofitting}

The sustainable retrofitting of housing stock addresses the need for reducing energy consumption (Jones et al, 2013) and can be carried out in either shallow or deep forms. Shallow retrofit focuses on the installation of cost effective measures and can enable $10-30 \% \mathrm{CO}_{2}$ emissions reduction, while deep retrofit addresses the whole house and can enable up to $80 \% \mathrm{CO}_{2}$ emissions reduction, albeit at a significant increase in costs as such efficiencies are approached (Jones et al., 2013). While retrofitting of existing housing to $80 \% \mathrm{CO}_{2}$ emissions reductions is costly and technically difficult, achieving reductions of $50-60 \%$ is more economically and technically achievable (Bothwell et al., 2011). Thorpe (2010) and Malina (2013) have outlined a hierarchy of more sustainable retrofit interventions and prioritise the removal of air leaks and increased thermal performance.

Better home insulation is one of the Committee on Climate Change's (CCC) key targets for reducing carbon emissions in the domestic sector (CCC, 2014). The 'hard-to-treat' nature of the pre-1919 
housing stock affects the practical implementation and cost effectiveness of retrofitting (Dowson et al., 2012), as solid wall insulation's economic payback period could be in excess of 25 years (Peacock, 2010). Hard-to-treat is defined as having no mains gas heating system and/or a solid wall home. $38 \%$ of the English housing stock is classified as in this way (Centre for Sustainable Energy, 2011 ) and only $15 \%$ of solid wall homes are expected to be insulated by 2050 due to low affordability (Dowson et al., 2012). Nevertheless, old homes may possess the potential to match or perform better than the SAP rating of modern housing as a result of retrofitting (Yates, 2006), as demonstrated by retrofit of pre-1919 houses for the 'Retrofit for the Future' programme in the UK (Baeli, 2013). Subsequently, this type of housing is thought to have a key contribution to attaining the UK government's carbon reduction targets (Power, 2008; Atkins and Emmanuel, 2014).

\subsection{Adopting a sustainable retrofit}

Retrofit projects are affected by economic, technical, social, legal and political factors (Gillich and Sunikka-Blank, 2013; Pelenur, 2013) which act as a barrier against, or a driver for, the retrofit process, and influence homeowners' decisions. These will be considered briefly in the following sections.

\subsubsection{Legal and political influences.}

Government policies, such as the Energy Company Obligation (ECO) and Green Deal (Guertler, 2011), manifest the political drivers for retrofitting as part of the legal commitment to carbon reduction under the UK Climate Change Act 2008 (Pelenur, 2013). The Green Deal permitted loans to support homeowners and tenants in England, Scotland or Wales to make energy-saving improvements (e.g. insulation, double glazing and renewable energy generation). The loans were repaid through the savings made in energy bills and shaped a novel concept in UK law since they were transferred with the property. However, the end of Green Deal in July 2015 led to concerns regarding the affordability of retrofit measures and government's commitment to supporting the scheme, leading to it being considered unsuccessful and criticised by the industry. The ECO remains as a major policy for domestic retrofits in the UK, although only targets primary measures such as insulation and draught proofing rather than deep retrofits (Ofgem, 2016).

On the other hand, compliance with building regulations can prohibit retrofit, because approximately $25 \%$ of the pre-1919 housing stock is listed or located within a conservation area. Conservation issues can also limit the opportunity to retrofit the oldest housing stock a due to the stipulation that design details appropriate to the character of homes (such as age, construction type and condition) should be considered (Moorhouse and Littlewood, 2013). This prohibits the installation of retrofit measures such as external wall insulation and double glazing and places greater pressure on the rest of the stock to yield significant carbon emission reductions (Boardman, 2007b). 


\subsubsection{Economic influences}

Cost is the major barrier being faced in the uptake of energy efficiency retrofit measures (Thorpe, 2010; Fawcett, 2014; Bhuiyan et al., 2015) and the retrofit of pre-1919 properties is typically $15 \%$ more expensive than for relatively new housing stock (Jenkins, 2010). Furthermore, cost data on low carbon retrofits are inconsistent (Fawcett, 2014), with cost estimates for an $80 \% \mathrm{CO}_{2}$ reduction ranging from between $£ 30,000$ to $£ 100,000$ (Thorpe, 2010) to $£ 131,000$ under the 'Retrofit for the Future' programme (Fawcett, 2014). As the cost of retrofit influences capital outlay and payback period, this may affect the homeowners' decision to retrofit their homes because their occupancy of the property will not be long enough to witness a return on their investment (Guertler, 2011; Tovar, 2012).

On the other hand, financial incentives, such as variable stamp duty, variable council tax and feed in tariffs can affect energy demand (UKGBC, 2013) and evidence suggests that improving a dwelling's environmental rating presents higher market value (DECC, 2013). Economic viability is important for a successful retrofitting process (Galvin and Sunikka-Blank, 2013), with measures being deemed economically viable if their total cost is lower than energy cost savings throughout their lifetime (Booth and Choudhary, 2013). Nevertheless, Galvin and Sunikka-Blank (2013) argue that theoretical energy consumption calculations are frequently over-estimated and may result in a financial shortfall through lower savings (Booth and Choudhary, 2013; Milsom, 2014).

\subsubsection{Technical influences}

While sustainable retrofits have the potential to increase the environmental performance of pre-1919 buildings (Baeli, 2013 and Hartless \& Standen, 2013), if carbon emission reduction levels are not met, energy efficiency measures might have been poorly installed (Stafford et al., 2011). Poor installation of solid wall insulation can present not only performance gaps, but also health hazards caused by moisture build up and overheating (Strube et al., 2012). One of the key technical factors challenging the performance of retrofitted homes is air tightness, with the mean air permeability of solid wall housing equating to 10 air changes per hour $\left(\mathrm{ach}^{-1}\right)$, compared with the Passivhaus standard of $0.6 \mathrm{ach}^{-1}$ (Banfill et al., 2011). Dowson et al. (2012) highlight the difficulties faced in achieving airtightness in the oldest building stock. Without improving the air tightness of homes, building fabric improvements could prove counter-productive (Atkins and Emmanuel, 2014). As far as technical interventions are concerned, there is a shortage of skills among the construction workforce to carry out low carbon retrofit of old buildings (Plimmer et al., 2008), prompting the National Energy Foundation (NEF) (2014) to outline how a lack of skills prohibits a holistic approach to retrofit. There is a need for widespread training and education in a variety of construction roles to enable the desired carbon reductions in existing housing stock (Gleeson et al., 2011). 


\subsubsection{Social influences}

Finally, behaviour change may achieve the greatest level of energy savings in the domestic sector (Galvin and Sunikka-Blank, 2013; Elsharkawry and Rutherford 2015). The attitudes of housing occupants are key to the successful implementation of retrofitting processes, and obtained through education and policy reforms by the government (Elsharkawy and Rutherford, 2015), to mitigate the impact of the 'rebound effect' which sees the occupants making negative behavioural choices based upon savings accrued through increased energy efficiency of their home (Boardman, 2007a; Jenkins, 2010). Other social influences include the potential disruption caused by retrofitting (Dowson et al., 2012) and homeowners struggle to balance thermal issues against heritage and aesthetic concerns which often overlap or clash (Sunikka-Blank and Galvin, 2016). Homeowners foresee retrofit presenting more problems than benefits (Plimmer et al., 2008). Furthermore, there is general lack of awareness and interest in adopting low carbon retrofit measures (NEF, 2014) and less appreciation of energy efficient refurbishment (Power, 2008).

\section{Research Methods}

The housing stock in England is estimated to have 22.8 million properties, of which $20 \%$ are pre-1919 homes (DCLG, 2015a). Although the proportion of high energy performance houses has increased from 5\% in 2005 to $28 \%$ in 2015 (Smith, 2015) and the number of retrofits being undertaken annually was 2.9 to $5 \%$ of the existing number of homes by 2013 (Eames et al., 2013), this is still far below the required level to meet the government's carbon reduction targets. Consequently, retrofit measures in the pre-1919 housing stock are necessary to contribute to carbon emissions reduction in the UK. This paper explores the drivers and barriers to retrofitting of owner-occupied pre-1919 housing. Based on the literature review, three themes were investigated with regards to retrofit in this study, namely: social viability (are homeowners willing to retrofit?); economic viability (is retrofitting affordable?); and technical viability (can retrofit improvements be delivered?). This exploratory research was carried out to develop deeper understanding of the viability for retrofitting pre-1919 owner-occupied homes. A mixed methods approach was adopted using a survey to collect data from pre-1919 homeowners living in the UK combined with semi-structured interviews with the homeowners living and domestic energy efficiency and retrofit experts in the market.

Questionnaire survey: A survey was developed to identify factors influencing the pre-1919 homeowners' decision to retrofit by focussing on the social and economic themes explored above. This was pilot tested, and based on the feedback received, was modified and sent to a sample of 150 pre-1919 homeowners living in the UK, using convenience and snowball sampling techniques to maximise the response rate across the UK. The research team's professional network was also used to gain responses from householders. In total, there were 43 respondents and these quantitative data were integrated with the qualitative semi-structured interview data to generalise the findings. 
Household and Expert Interviews: Semi-structured interviews were also conducted with ten owneroccupiers of pre-1919 homes in the UK and four industry professionals with experience of sustainable and low carbon domestic retrofitting (Table 1).

Table 1: Details of the interviewees

\begin{tabular}{|c|c|c|}
\hline No & $\begin{array}{c}\text { Interviewee } \\
\text { code }\end{array}$ & Details of the pre-1919 home \\
\hline \multicolumn{3}{|r|}{ Household interviews } \\
\hline 1 & $\mathrm{HI} 1$ & $\begin{array}{l}\text { An old house built about } 130 \text { years ago. It has stone outside and } \\
\text { bricks inside. It has a cavity but it is rubble filled. }\end{array}$ \\
\hline 2 & $\mathrm{HI} 2$ & $\begin{array}{l}\text { A detached property built in } 1910 \text {. It has } 3 \text { bedrooms. An extension } \\
\text { was put on the front as a main entrance porch. }\end{array}$ \\
\hline 3 & HI3 & $\begin{array}{l}\text { A mid-terraced house constructed pre-1900 (1890). It had an } \\
\text { extension at the back. }\end{array}$ \\
\hline 4 & $\mathrm{HI} 4$ & A detached house built around 1870. \\
\hline 5 & HI5 & $\begin{array}{l}\text { The house is detached and has four storeys including basement } \\
\text { converted into four flats. }\end{array}$ \\
\hline 6 & HI6 & $\begin{array}{l}\text { A detached house which was built in } 1850 \text {. In this house, the loft was } \\
\text { converted into living space. }\end{array}$ \\
\hline 7 & $\mathrm{HI}$ & A detached house with a basement converted into a flat. \\
\hline 8 & $\mathrm{HI} 8$ & $\begin{array}{l}\text { A detached house built of bricks with a slate roof in } 1897 \text {. It has } \\
\text { single glazed church-leaded windows and has a finished attic. It is in } \\
\text { a conservation area. }\end{array}$ \\
\hline 9 & HI9 & $\begin{array}{l}\text { Built in } 1918 \text {, the first of a series of six bay-fronted (i.e. top and } \\
\text { bottom) terraces originally built for fire-fighters. Loft was converted } \\
\text { and there is a large room there with double-glazed skylights. There } \\
\text { are original sash windows; some are restored and all are single- } \\
\text { glazed. }\end{array}$ \\
\hline 10 & $\mathrm{HI} 10$ & $\begin{array}{l}\text { A very old home where double glazing, solar PVs and under floor } \\
\text { heating system is installed. }\end{array}$ \\
\hline \multicolumn{3}{|r|}{ Expert interviews } \\
\hline 1 & El1 & Award-winning sustainability writer specialising in old housing. \\
\hline 2 & $\mathrm{El} 2$ & $\begin{array}{l}\text { Contract and Home Improvement Manager having experience of } \\
\text { working with pre-1919 housing and homeowners. }\end{array}$ \\
\hline 3 & EI3 & $\begin{array}{l}\text { Award-winning energy consultant for a community housing } \\
\text { association. }\end{array}$ \\
\hline 4 & El4 & SuperHomes member and energy advice consultant. \\
\hline
\end{tabular}




\section{Data Analysis and Discussion}

The research findings are presented and discussed under the three main themes of sustainable retrofitting; social viability, economic viability and technical viability.

\subsection{Social viability}

The social viability of retrofit is determined by pre-1919 homeowners' attitudes at an individual household level.

\subsubsection{Attitudes to retrofit}

This question was aimed to assess the pre-1919 homeowners' attitudes towards low carbon retrofit. The answers provided by the questionnaire respondents were measured on a 5 point Likert scale on a continuum from 'agree' to 'disagree'. Figure 1 presents the frequency of each response out of the five pre-coded responses for all nine items relating to participants' awareness of, and importance attributed to, retrofit. The answer to the first four items in figure 1 suggest the participants' attitudes towards the environmental aspects of retrofitting. The mode scores are 5, 3, 5 and 5 respectively for the above four items, suggesting that the majority of participants demonstrated a high level of awareness of the schemes supporting energy efficiency improvements, that reducing their home's energy consumption is important to them, and that they have increased awareness of methods of reducing energy consumption.

The findings revealed that reducing carbon emissions is not their primary concern. Although the respondents agreed with the importance of carbon emissions reduction, they were not inclined towards the implementation of retrofit to reduce emissions. Nevertheless, responses to these four elements demonstrate the tendency of positive attitude towards the environmental protection and low carbon retrofitting. This result is in agreement with the responses given to one of the survey questions where the majority of respondents consider themself environmentally conscious. In Figure 1, the mode scores are presented on the right-hand side of each bar chart and indicate the numerical value equivalent to a pre-coded response which had the highest frequency. 


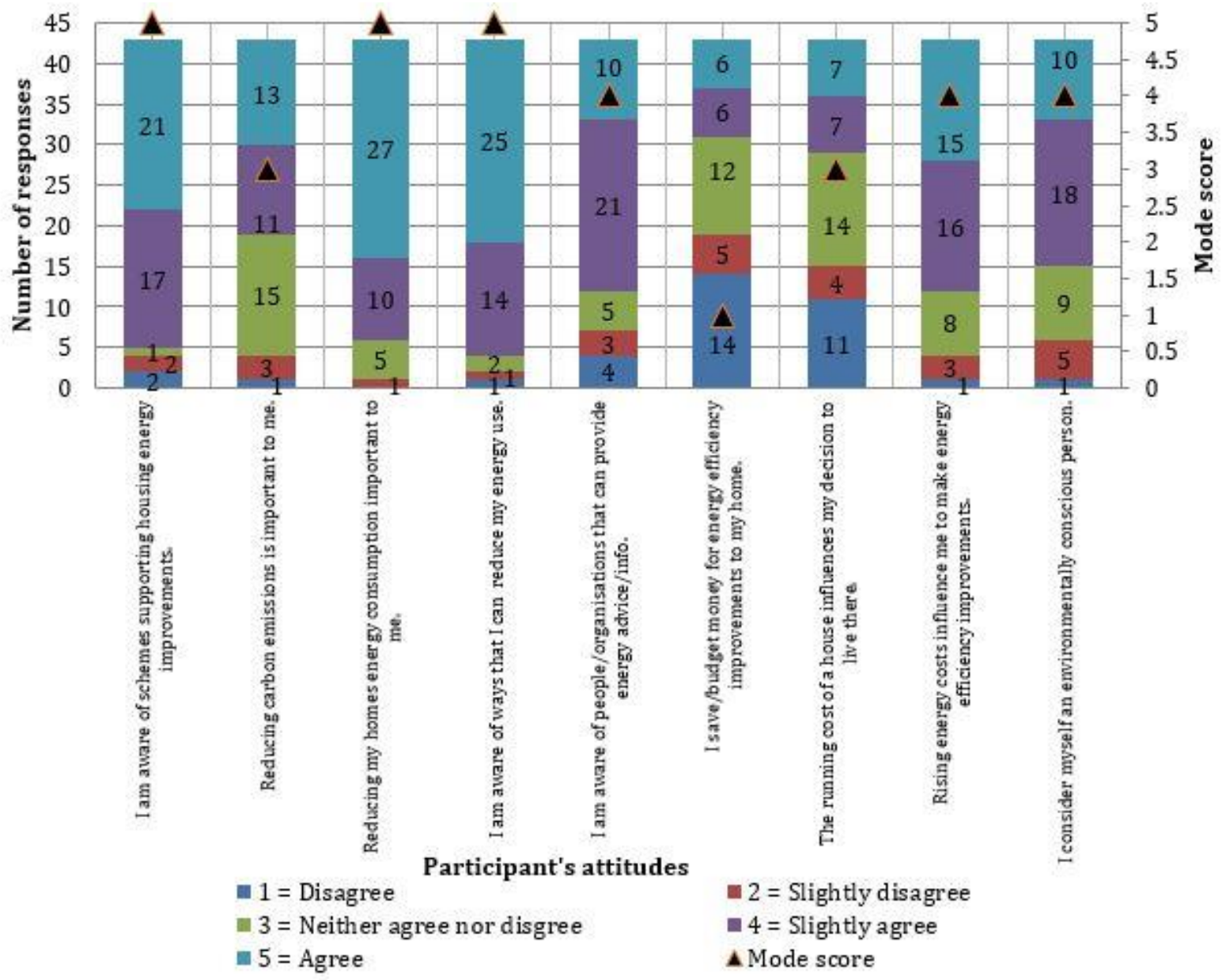

Figure 1: Attitudes towards and awareness of retrofit in pre-1919 homes

The respondents were asked about their intention to retrofit their homes in future. $33 \%$ indicated a future plan for carrying out between 1 and 5 energy efficiency improvements in their homes and 22\% have already planned to implement at least one energy efficiency improvement. The energy efficiency measures may include energy efficient lighting, floor, solid wall \& cavity wall insulation, draught proofing, double \& triple glazing, boiler upgrade and low carbon technologies such as solar PV panels, ground source and air source heat pumps. However, $33 \%$ of the respondents have no plan to carry out energy efficiency improvements for the next 5 years, despite the positive attitude they expressed towards the natural environment. This might have been due to the implementation of some energy efficiency measures that the householders had already adopted in the past and diminishing returns, as adopted measures increase.

Figure 2 presents pre-1919 homeowners' reasons to invest in energy efficiency improvements. It shows that the majority of participants intend to spend money for aesthetic and home comfort improvements and indicates that reducing utility bills is the second most important motivation to invest by the participants. The figure shows that the majority of participants are not inclined to spend money 
with the aim only to reduce carbon emissions and represents a low priority for retrofitting among pre1919 homeowners.

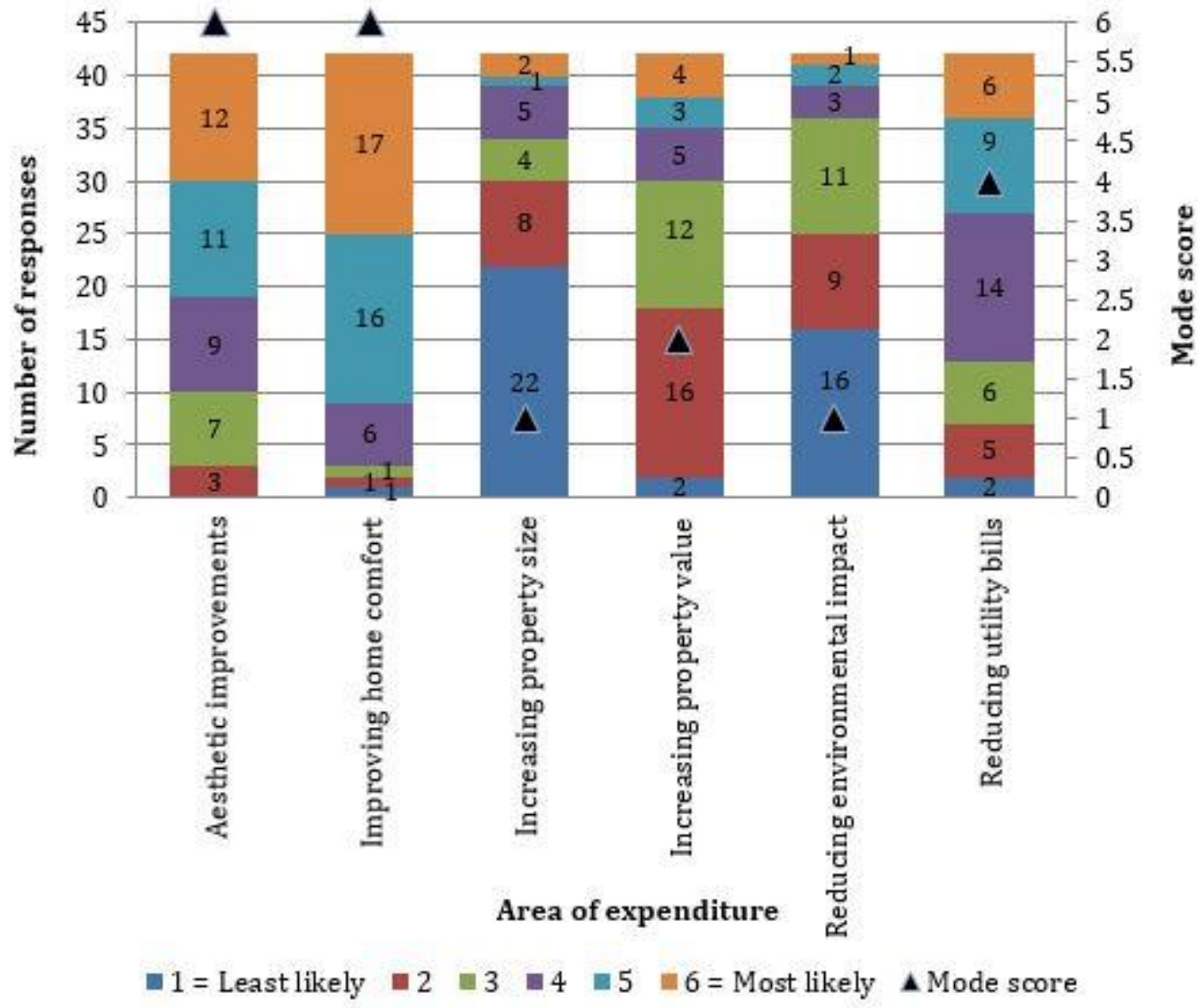

Figure 2: Pre-1919 homeowners' intention of spending money on retrofit

As opposed to the questionnaire respondents, all homeowner interviewees (HIs) have adopted energy efficiency measures, with double-glazing and loft insulation being the most predominant measures adopted. They have taken the basic measures which offer a higher return on investment (ROI). Three HIs mentioned the replacement of their old boiler with the energy efficient one. Expert Interviewee 4 (EI4) suggested that the general attitude towards low carbon retrofit is changing for the better; however, El1 was more cautious in his optimism for retrofits indicating that there is no collective attitude, but instead a disparity amongst the general public. Similar to the questionnaire findings, Hls suggested that homeowners are unlikely to act solely in the interest of reducing carbon emissions, outlining the requirement to promote other benefits such as saving energy bills arising from the retrofit process.

"Retrofitting is not in our list of priorities at the moment, but if we want to consider retrofitting, maybe loft conversion or insulation is the one". [HI8]

\subsubsection{Awareness and knowledge}


The questionnaire revealed the level of participants' awareness and knowledge of low carbon retrofit (see Figure 3). It indicated that there is a high level of knowledge of energy efficiency measures available for implementation, with respondents having an average prior knowledge of 12 measures from the 18 presented. The results shown in Figure 3 reveal that energy efficiency measures such as insulation, glazing, draught proofing, energy efficient lighting and solar PV panels were the most commonly known among the questionnaire respondents, whereas renewable energy technologies (excluding solar PV panels), smart monitoring and new heating controls were the least known. This could be due to the complexity of advanced building and renewable energy technologies. Mechanical Ventilation with Heat Recovery (MVHR) systems were not known to any of the participants (see Figure 3). While prior knowledge and awareness about solid wall insulation was reported by only $58 \%$ of the respondents, it is still encouraging to note that more than half the participants were aware of the measure.

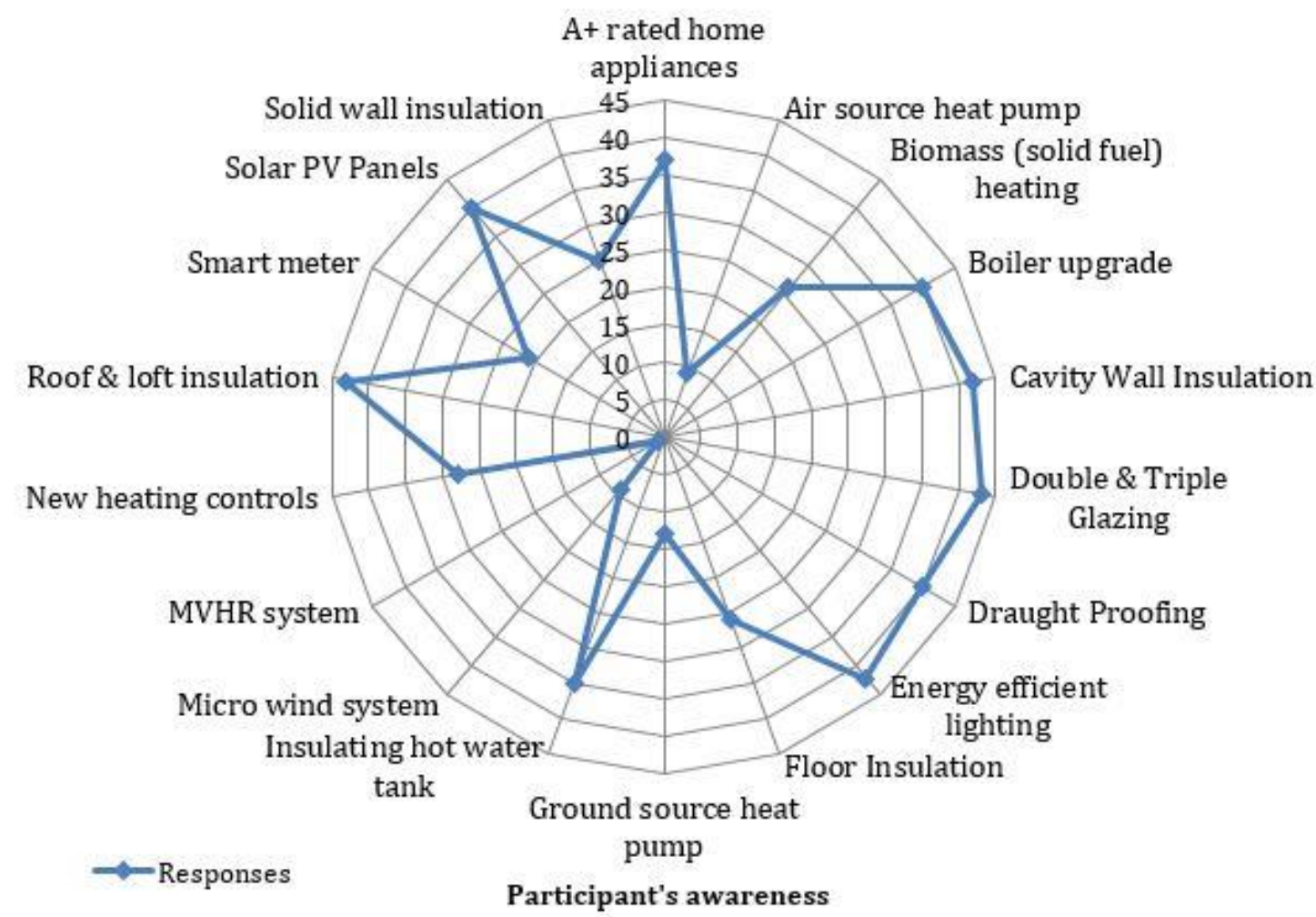

Figure 3: Awareness of energy efficiency measures among the participants

Findings from the interviews suggest that for retrofitting to be viable for pre-1919 homeowners, awareness needs to be raised among this demographic to improve their home's energy efficiency and reduce carbon emissions. El1 emphasised homeowners' lack of awareness on low carbon retrofit measures in their pre-1919 homes.

"We did not even know what we can do to make it better. So, I can say that lack of knowledge is a big barrier. For example, for changing the heating system, we knew that we had to change the pipe and systems, but we did not know an exact figure that would cost us. If I knew how 
much this change financially would be or how much saving it would give us, we would have done it earlier." [HI4]

Homeowners were asked if they conducted their own research into improving energy efficiency of their property and they provided mixed answers including;

"No, I probably drop into the apathy group. I am not particularly bothered at this stage" and "No that's not something that we have looked at recently".

However, other interviewees indicated that they have been able to easily collect information from internet sources and television programmes, contrasting to El1's views that:

"The easily available knowledge and understanding of what you can do is limited"

El1 emphasised the need for education to ensure homeowners understand what can be done to make their inefficient pre-1919 homes more energy efficient. Homeowners were asked if they had sought information about energy efficiency retrofitting. HI6 stated;

"Not really, I have been approached by people about double glazing before and I initially thought we cannot do it due to the house being a listed building. I was thinking we cannot do much. I did not know about what we can do for example it never occurred to me to see if we can install solar panels".

In contrast, two interviewees reported an opposite perspective which may be due to their educational and professional background related to energy. This suggests that people may be interested in retrofit to reduce energy and carbon emissions as long as they have knowledge and understanding of it. There appears to be very limited advice and support on energy efficiency and low carbon retrofit for homeowners. This indicates that intermediary organisations or support mechanisms such as energy advice services can help drive the retrofit agenda forward. This will help address the government's fuel poverty agenda because $75 \%$ of the households in England that are classed as fuel poor live in a dwelling that was built pre-1965 and $42 \%$ fuel poor properties are owner occupied (Department for Business, Energy and Industrial Strategy, 2017).

"We consider ourselves as a knowledgeable family due to the job of my husband (property investment company owner) and we were also postponing these changes for many years". [HI6]

\subsubsection{Improving home comfort}

Responses to the questionnaire revealed that home comfort is the primary area where pre-1919 homeowners were likely to invest money and is one of the most important drivers when considering energy efficiency retrofit improvements (see Figure 2). This indicates that energy and carbon reduction may not be a priority for the respondents. HI5 identified how her home is often cold to live in before suggesting improved comfort as a prime retrofit motivation. Similarly, El4 suggested that improving comfort was a key driver when she retrofitted her pre-1919 home in 2006, describing it as an "old cold draughty house" that was significantly improved following the retrofitting process. HIs 
outlined the comfort benefits retrofitting presents. This can have financial and environmental (carbon emissions) as well as health implications.

"To be honest, all changes were for the comfort of me and my family. Energy efficiency is important, but I did not start making those changes for reducing carbon emissions or energy efficiency. Comfort and cost are the most important factors". [HI6]

The findings suggest that home comfort is a major driver to invest in retrofit. Draughts in the older properties are an issue and may result in higher energy consumption due to the performance of the house.

"We have this problem all the time. The cold is coming inside from underneath the door, the entrance to the building, sash windows, the door gaps and literally everywhere". [HI6]

\subsubsection{Disruption to home life}

Pre-1919 properties are difficult to deal with in terms of carrying out retrofit and may cause a lot of disruption to the occupiers. However, the results presented in Figure 4 show a spread of results, outlining the diverse opinions of the pre-1919 homeowners who participated in the questionnaire survey. EI3 identified disruption to home life as a barrier to retrofitting and HI5 reinforced this argument by stating that;

"Spending money and the hassle are the biggest preventive barriers to energy efficient retrofit measures in homes".

However, El4 suggested a potential solution to this barrier by relaying how central London estate agents are distributing energy efficiency information packs to customers. Their aim is to present energy efficiency improvements that can be made alongside the expected household improvements, reducing the disruptive nature of energy efficiency retrofit. 


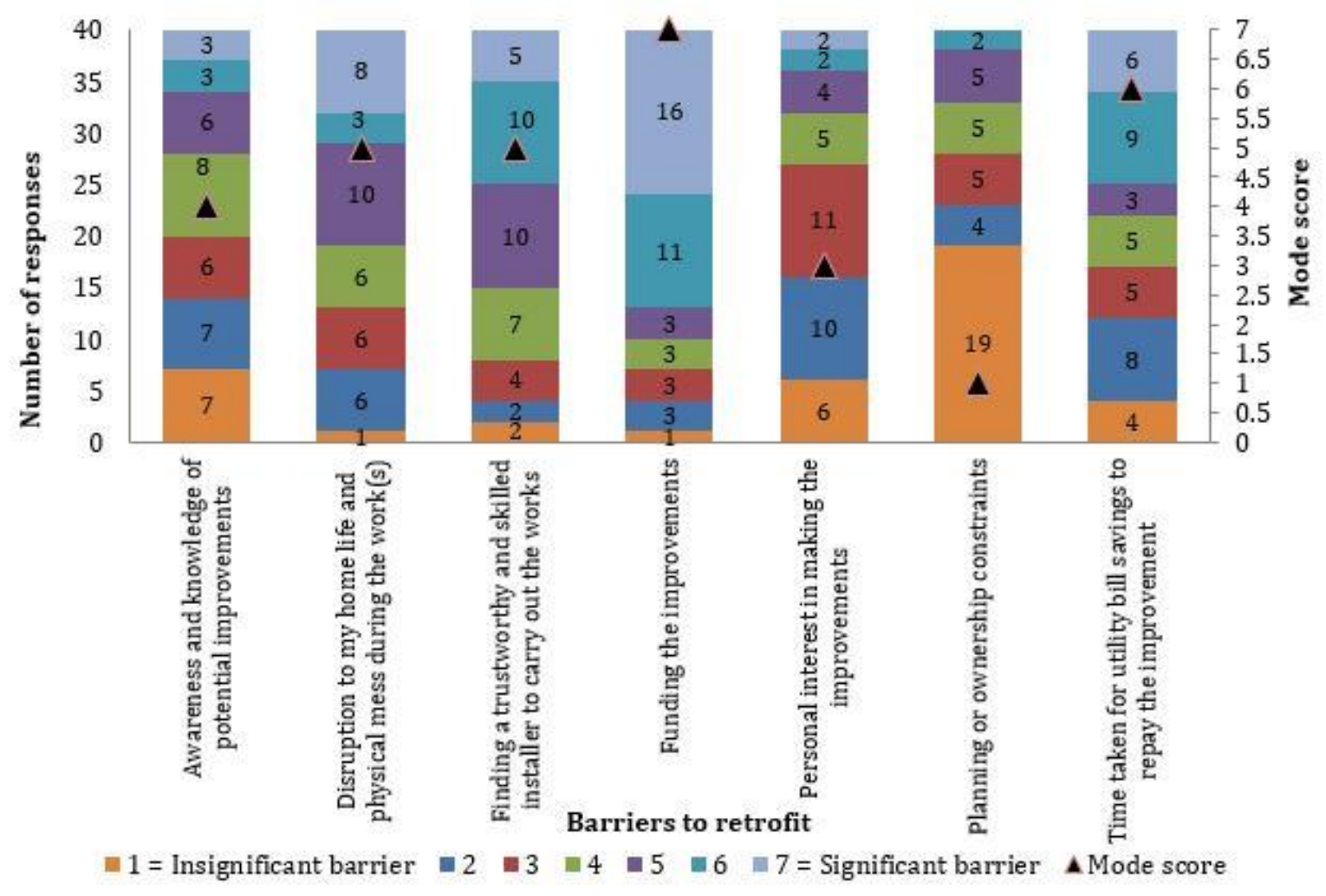

Figure 4: Barriers preventing pre-1919 homeowners from making energy efficiency improvements

\subsubsection{Personal interest}

Lack of personal interest in energy efficiency and carbon emissions reduction were not perceived to be key barriers in the questionnaire, whereas aesthetic improvements were considered as a priority (see Figure 4 and Figure 2). The improved appearance was considered as a leading requirement when considering energy efficiency interventions in pre-1919 homes (see Figure 2). This demonstrates that the aesthetic improvements can be associated with energy efficiency measures. However, personal interest is one of the main issues emphasised by the interviewees in this study. Hls claimed that their personal circumstances were preventing them from making energy efficiency improvements in their home.

"We have the idea of a complete refurbishment in the house instead of partial or minor changes. I do prefer to have more time and money to do all the changes in one run. Definitely personal interest is among the most influential factors about making decision". [HI8]

This was evident across a range of interviewees' ages with responses including:

"At our time now, is it worth us spending thousands of pounds or should we be saving that for our healthcare needs or passing it onto the next generation?".

"This is our first house and not one that we are going to stop in forever, so we would probably see it as something that is not worth doing right now". 
In general, Hls stated that energy efficiency retrofit is not at the top of their agenda, and that expenditure on luxuries could be more important to them.

"If we had that sort of money available, then I could think of better things to spend it on".

This not only indicates personal interest, but also issues around priority and need for financial investment. In addition, different views and interests of family members can impact retrofitting due to collective nature of the decision-making process. For example,

"I don't think I would be considering any of the energy efficiency measures, because it is not only for me to decide. There are other three families living in this house and all should agree on making any change to the building. It would be difficult to come to an agreement". [HI5]

\subsection{Economic viability}

This study has revealed that reducing utility bills can be considered as one of the main drivers to invest in energy efficiency home improvements. The financial importance of energy efficiency improvements can be seen as the most important barrier in Figure 4 (based on the mode scores). This indicates that retrofit needs to be a financially viable option for homeowners due to significant investment on the complex and old pre-1919 housing stock. The owner-occupiers want a return on their investment and when asked about the biggest motivation for HIs to retrofit their properties, their answers included; "Cost against savings" and "I suppose that the biggest thing would be saving money".

\subsubsection{Funding the retrofit}

Pre-1919 homeowners' ability to fund energy efficiency improvements was considered a major barrier and the time taken for utility bills saving to repay the improvement is shown to be the second factor discouraging retrofitting. As presented in Figure 4, 40\% of the respondents identified difficulty in funding energy efficiency improvements, while a further $28 \%$ identified it as the second most prominent barrier. A further financial barrier observed in the questionnaire was the apparent lack of budgeting for energy efficiency improvements, with $28 \%$ of the respondents giving a positive indication that they save money for future improvements (Figure 1). The major barriers around funding suggest the cost implications of retrofitting.

The majority of Hls claimed that initial capital cost is the main barrier to retrofit; this is even more of an issue when people are on a tight budget with many facing the issue of fuel poverty. Els stated that most of the households in need of low carbon retrofit are those who cannot afford it financially. $75 \%$ of the households that are classed as fuel poor live in a home that was built pre-1965, whereas only $54 \%$ of the non-fuel poor households live in similarly aged homes (Department for Business, Energy and Industrial Strategy, 2017).

\subsubsection{Reducing utility bills}


The majority of His agreed that pre-1919 older homes are expensive to run due to high energy bills. HI6 stated about the inefficiency of the pre-1919 home;

"It is extremely expensive. The running cost is unbelievable. Actually, once we had a call from the utility company to find out the reason for the enormous gas usage. They were suspicious that there might be a gas leakage somewhere saying that it's being the most expensive gas bill that they have ever seen".

Reducing utility bills was considered as a main driver for the adoption of energy efficiency measures in pre-1919 homes by the respondents. $72 \%$ of the respondents indicated that increasing energy costs will influence them to make energy efficiency improvements to their home (Figure 1). 'Rising energy prices' is a likely driver for the retrofit of homes where the reduction of electricity and gas demand will help to reduce carbon emissions. However, retrofit requires significant capital investment by the homeowners which can then paid back through reduced energy bills and cost savings. This suggests that large capital investment for retrofit offers financial benefits throughout the operation of the property which homeowners need to be aware of.

\subsubsection{Affordability and external funding}

The survey responses suggest that 'external funding' is an important factor for retrofitting and Figure 5 presents the main financial incentives which can motivate the home owners to carry out energy efficiency retrofit. 'Tax reductions' such as council tax emerged as the strongest influence among all the financial incentives. In contrast, 'loans and salary sacrifice schemes' were less influential financial incentives. This is likely to be due to the financial commitment homeowners are bound with as part of the funding. This suggests that homeowners can be better motivated by initiatives that reward energy efficiency improvements rather than by the availability of funding itself. The lack of influence from government loans and sacrifice schemes could be derived from personal preferences, a notion HI3 expressed:

"If we are going to have something we have always saved for it and not taken out loans ". There is an issue of affordability with regards to retrofit; El2 suggested that the energy efficiency products such as insulation and double-glazing need to be affordable in the market, while HI1 noted;

"You need to have quite a lot of disposable income".

EI4 advocated better affordability, suggesting a change to the value added tax (VAT) applied on energy efficiency measures to reduce the cost of retrofitting. However, according to the UK VAT Act 1994, the reduced rate applies to the installation of certain energy-saving materials and equipment by the government. EI2 believes that the major barrier to retrofitting is the lack of financial support in place due to significant cost implications;

"Since the cuts, it has had an impact in terms of the average person being able to afford it, for the average person on the street without financial support; I do not think it will ever go as well as when the funding was in place". 
An additional viewpoint expressed by one of the Hls was that the government should contribute towards the capital cost of retrofitting. HI2 outlined how the government and homeowners both benefit from retrofitting in many ways which include reduced energy bills and carbon emissions, yet only homeowners are expected to pay. There was an agreement in the data collected that better affordability and funding assistance will increase the viability of retrofit.

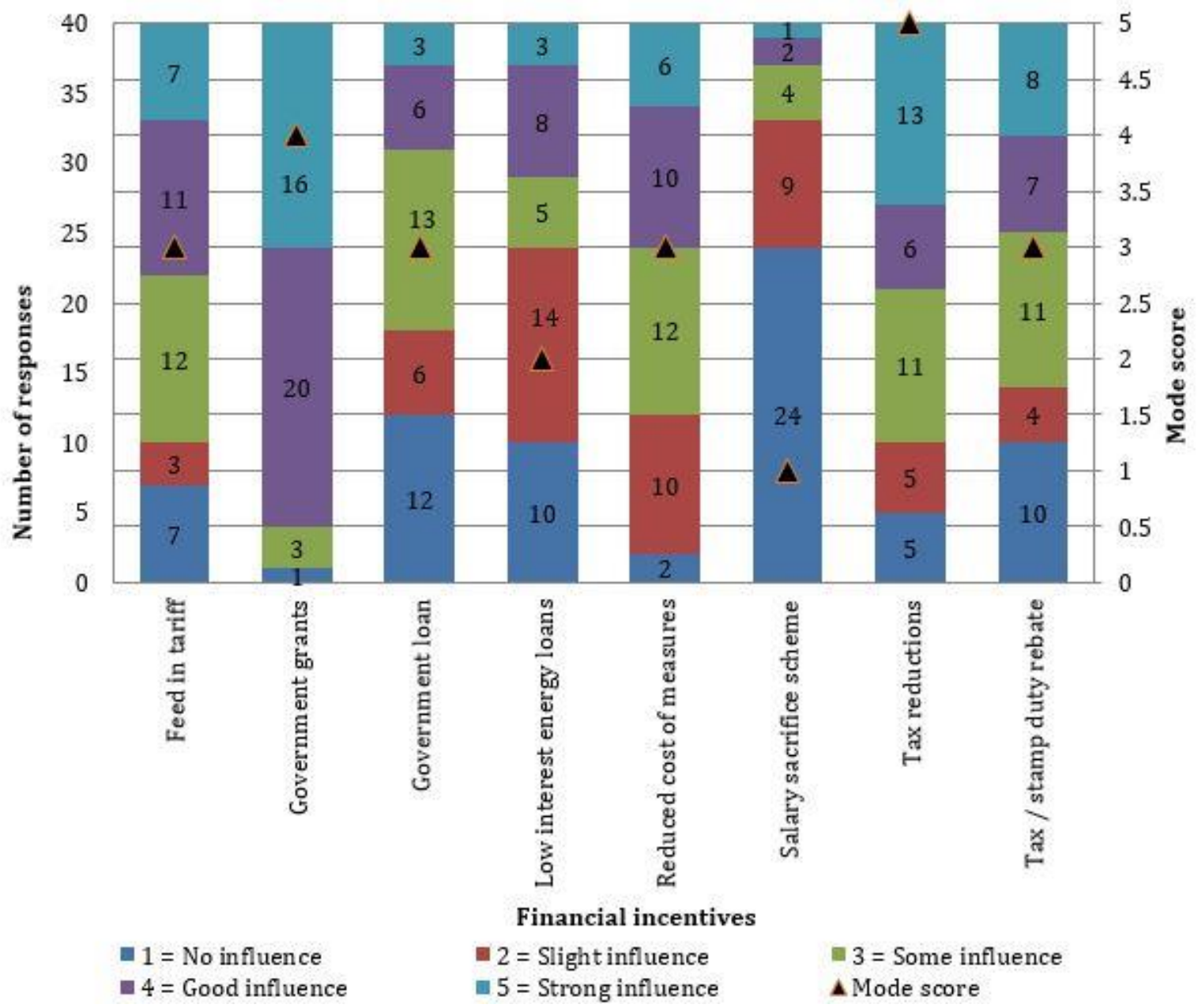

Figure 5: Influence of financial incentives on homeowners' motivation to enhance energy efficiency

Hls provided mixed opinions on the influence of financial assistance. While some reacted positively, others dismissed the notion that it would influence them stating that there are "too many unknowns" when entering into financial support schemes. With regards to financial assistance, HIs claimed that prior schemes such as Green Deal had been complex and largely unsuccessful with others believing they would enable more retrofits. HIs, when asked if a funding scheme such as Green Deal and Energy Company Obligations (ECO) would increase the likelihood of making energy efficiency improvements emphasised that the national government has a key role to play through policy mechanisms. For example,

"Government funding scheme definitely increases the likelihood of energy efficiency improvements, if we are aware of their existence and also what exactly they are". [HI3] 
"A sensible government scheme coupled with good advice might make me more likely to revisit some of the options". [HI8]

EI2 asserted the need for a long-term plan that forms part of a collective strategy that acknowledges the cost, but is prepared to run in excess of 20 years in comparison to the short duration of the Green Deal. El4 advocated that the UK should follow the political lead of Germany, citing the adopted 'pay as you save' scheme as highly successful in enabling retrofits for homeowners. The consensus collected from the Els was that there is a lack of government policy regarding retrofit. El1 remarked how he believed government does not have the inclination to try retrofit schemes again due to the historic failures of previous schemes such as the Green Deal and HI9 linked energy efficiency to health benefits by stating;

"I think that the government should actively support retrofitting to improve health outcomes and reach carbon emissions targets".

The interview and questionnaire results indicate that innovative funding models are expected to increase the viability of pre-1919 homes' retrofitting by financially facilitating the homeowners.

\subsubsection{Increasing property value}

$7 \%$ of the respondents considered 'increasing property value' as an important criterion for making decisions to retrofit (see Figure 2). However, energy efficiency and reduction in carbon emissions do not have a priority for homeowners. Investment in energy efficiency interventions within old and inefficient homes such as pre-1919 can increase the overall value of property.. The majority of HIs are living in pre-1919 detached type homes and believe that retrofit can add value to their pre-1919 property;

"I would spend money for the appearance of the house (inside and outside) and also to make the house warm". [HI6]

The importance of increased property value was observed in the HIs, with one interviewee stating;

"We would need to know that any improvements that are made are seen as the value of the house when we come to sell it. Is it just going to be money thrown down the drain when we sell it, or is it going to add money to the house as well?".

This indicates that homeowners seek long term value added and financial gains. Energy efficiency improvements are viewed as an investment in households, with the motivation of added property value most likely to occur among homeowners intending to move home in the future.

\subsubsection{Payback period}

Payback period was emphasised in the interviews. Both HIs and Els reported reduced energy bills as a major advantage of retrofitting and argued that energy efficiency improvements could be paid back through the cost savings observed. The payback period on energy efficiency measures was considered by the interviewees as a potential barrier to retrofitting. HIs demonstrated concerns over 
the time required for return on investment on energy efficiency measures in homes and Els recognised long payback periods as a potential barrier to uptake low carbon retrofit measures such as solid walls which are expensive and technically complex to retrofit.

"Talking about the general public, they are going to think $£ 15 k$ is going to take a life time to repay that". [EI2]

"Payback times are very long. It is quite shocking. It takes long time to get the result. I only choose methods which make immediate changes in the comfort of my family in the house." [HI6]

This could be due to financial position and affordability which means if they have investment, they will use it for making their home energy efficient and comfortable regardless of the length of the payback period.

\subsection{Technical Viability}

\subsubsection{Retrofit potential}

Even if pre-1919 homes have significant potential to reduce carbon emissions, El1 outlined that achieving carbon reductions between $70 \%$ and $80 \%$ is not feasible for each household, and called for realism in retrofit expectations. :

"You are never going to get the standard of a new home with regards to fabric performance or energy efficiency, but we can certainly do a lot to make the house more energy efficient and sustainable." [El1]

This led El1 to advocate the adoption of simpler energy efficiency measures (e.g. draught proofing and secondary glazing), reducing heat loss rather than focussing on technology based measures that present greater technical and economic challenges to the homeowners. The Els acknowledged retrofit to be the most sustainable option for the existing housing stock when considering wider sustainability issues beyond carbon emissions. However, many of the energy efficiency measures remain unexplored by pre-1919 homeowners due to a lack of advice and support.

\subsubsection{Industry skills}

The study found that there are not sufficient skills for sustainable retrofit in the UK construction industry. El4 and El1 identified lack of skills and knowledge in the construction workforce as a barrier to energy efficiency retrofit.

"There is a very poorly informed workforce and there is a complete lack of understanding about airtightness". [EI4]

This indicates that although there is a workforce delivering low carbon retrofitting in the UK housing sector in general and pre-1919 housing in particular, they are not fully aware of the latest energy efficiency techniques and trends; in particular the issue of air tightness was identified as problematic. El1 questioned the capability of the UK retrofit industry, indicating that energy assessors were often 
misguided to advocate politically driven measures, rather than assessing what the property requires on a case by case basis. A one-size-fits-all approach may not work in retrofitting.

"There is no one answer to retrofit a property because they may require different energy efficiency solutions based on their performance". [EI1]

This will require technical expertise for offering effective energy solutions and difficulty in finding a trustworthy and skilled installer has been identified as a barrier by the HIs. This is due to the saturation and complexity of the technology market where a large number of suppliers are providing energy efficiency measures. One of the Hls stated;

"I think that the problem is finding companies that we can trust"

There is a perceived lack of approachability and fear of being persistently pursued following the initial enquiry. El1 commented on the trustworthiness of installers and home energy advisors, believing that it is difficult for homeowners to obtain reliable advice when looking to retrofit;

"There are no people out there who can tell you how to do it, you cannot ring someone up and ask them to tell you how to retrofit your house or at least people who I would trust".

Els acknowledged their personal difficulties in finding trustworthy installers and assessors failing to identify what are the best options for individual households. This may indicate the need for improved energy advice and support for householders mechanisms at a local or national level.

\subsubsection{Planning constraints}

Pre-1919 homeowners may face planning constraints while getting approval of their energy efficiency retrofit design. EI2 and E14 perceived planning to be a frequent barrier to the installation of external wall insulation as part of retrofitting in Nottingham and London respectively where conservation areas are commonplace. In addition to legal constraints, the demand of homeowners to retain property features is another barrier facing the viability of retrofit. Both HIs and Els presented scenarios where retrofitting has not taken place due to the wishes of homeowners to retain certain property features. This may indicate an increasing role for government to facilitate low carbon retrofit through policy and planning measures.

\section{Discussion}

The study found pre-1919 homeowners' attitudes as a barrier to retrofitting; this aligns with NEF findings (2014) and Power (2008) who argue that there is a lack of knowledge and awareness regarding low carbon retrofit. In contrast, the questionnaire findings demonstrate an improved basic knowledge as the majority of the participants presented a good level of awareness of energy efficiency improvements. Despite increased awareness, carbon reduction was not a priority for pre-1919 homeowners with the biggest driver for retrofitting pre-1919 housing being improved home comfort. The level of understanding may need to be increased to scale up retrofitting to meet the carbon reduction targets. This is a concern given the importance of the domestic retrofit measure outlined by 
the CCC (2015) and could be due to the complexity of the subject of retrofit. This was noticed in the household interviews with several interviewees having considered solar PV panels despite not fully insulating their homes, as suggested by Thorpe (2010) and Malina (2013). The availability of advice and support is key within the UK housing sector. The national government and local authorities need to play their role in raising awareness.

Pre-1919 housing stock is often uncomfortable to live in due to energy loss and inefficiency. The findings suggest improving home comfort to be a priority and while retrofitting would not be aimed primarily at reducing emissions, it would be exhibited through reduced demand for space heating, the largest household consumer of energy. Bhuiyan et al. (2015) identified home comfort as one of the functional requirements of the pre-1919 households. There is an issue of disruption to home life with regards to retrofit. Dowson et al. (2012) identified that disruption to home life was a major barrier to homeowners undertaking retrofitting. This disruption can impact households and their routine life. This is an increasingly important issue as pre-1919 properties are difficult to deal with in terms of retrofit work and may cause a lot of disruption to the residents. However, in the long term, potential benefits of retrofit may outweigh the disruption caused. Power (2008) suggests that homeowners are likely to spend money for aesthetic improvements rather than purely on energy efficiency and the study identified this as the main priority for homeowners where they can gain an aesthetic value from energy efficiency measures such as new glazing, doors and external solid wall insulation.

Homeowners are motivated by financial gains and primarily restricted by funding making it clear that economics plays a key part in the viability of retrofitting. This indicates increasing importance of a strong business case for retrofitting. If the barriers can be overcome, retrofitting can offer an economic motivation that could instigate retrofits and lead to reduced carbon emissions from pre-1919 housing stock. Britnell and Dixon (2011) found that homeowners are financially motivated in pursuit of making energy efficiency retrofit improvements. This was observed in the questionnaire with reducing energy bills considered a leading area to invest money in. This suggests that the initial capital cost can be paid back by lower operational cost throughout the life cycle of the property; this is consistent with Thorpe (2010), Fawcett (2014) and Bhuiyan et al. (2015). The DECC (2015b) report that approximately $18 \%$ of the pre-1919 households live in fuel poverty and may not invest, while Dowson et al. (2012) outlined how low affordability is prohibiting low carbon retrofit. Long et al. (2015) state that retrofit schemes tend to offer positive results when marketed and hosted correctly. However, there were mixed opinions among Hls on the influence of financial assistance from various sources with tax reduction being the most desired motivation, followed by the government grants. In contrast, the survey respondents reported the least interest in the salary sacrifice scheme, probably because the money will be deducted from their income. The desire to see savings of energy bills is most likely caused by the inflation which gives rise to domestic fuel bills, and the expectation for energy bills to quadruple between 2010 and 2020 (Gleeson et al., 2011).Energy efficiency measures can increase 
the property value which can be one of the motivations for homeowners. The DECC (2013) reports that more energy efficient homes hold higher value, which would serve as a driver for retrofit and this study found that increased property value was one of the important decision-making criteria to support household improvements.

With regards to technical viability, Els were in agreement that retrofitting provides means of creating a sustainable building stock and reducing emissions, whilst recognising the other advantages that may be presented simultaneously. This is in agreement with Baeli (2013) and Hartless \& Standen (2013) who demonstrate the potential for carbon and energy reduction in pre-1919 housing. Retrofitting can be seen as technically viable for pre-1919 homeowners, with many innovative solutions available to reduce energy consumption. It is likely that this viability can be increased with research and development continuing to provide innovative solutions in what is a growing market. CCC (2015) believe that many technical solutions to retrofit are still being developed, while Stafford et al. (2011) highlight the importance of innovation on improving retrofits in the future. On-going development of materials and products will serve to reduce the embodied carbon emissions associated with energy efficient materials and measures, a challenge Iddon and Firth (2013) recognised in low carbon buildings. However, the focus remains on reducing operational carbon emissions and more attention is needed on embodied emissions, as suggested by lbn-Mohammed et al. (2013). One of the technical barriers to retrofit pre-1919 homes is the lack of skills and knowledge in the UK construction industry (Plimmer et al., 2008; Gleeson et al., 2011; NEF, 2014). It is essential that construction industry skills are improved to deliver a high quality retrofits.

\section{Conclusions}

This paper has explored the drivers and barriers to retrofit pre-1919 owner-occupied homes by applying a mixed-methods approach. The literature review emphasised the need to increase the retrofitting of complex and inefficient pre-1919 housing stock under the themes of social, economic and technical viability. The study findings are summarised in Table 2 . While homeowners recognise the value of retrofitting, they can have difficulties in its implementation due to a range of factors such as a low priority attributed to the process, lack of funding, disruption to home life and planning constraints. On the other hand, homeowners are likely to retrofit for financial reasons which may include reduced energy bills, added property value and government grants. Furthermore, the need for improving the home comfort and aesthetic improvements in the property are also the key drivers.

Table 2: Drivers for and barriers to retrofitting the pre-1919 owner-occupied homes 


\begin{tabular}{|c|c|c|}
\hline Social & 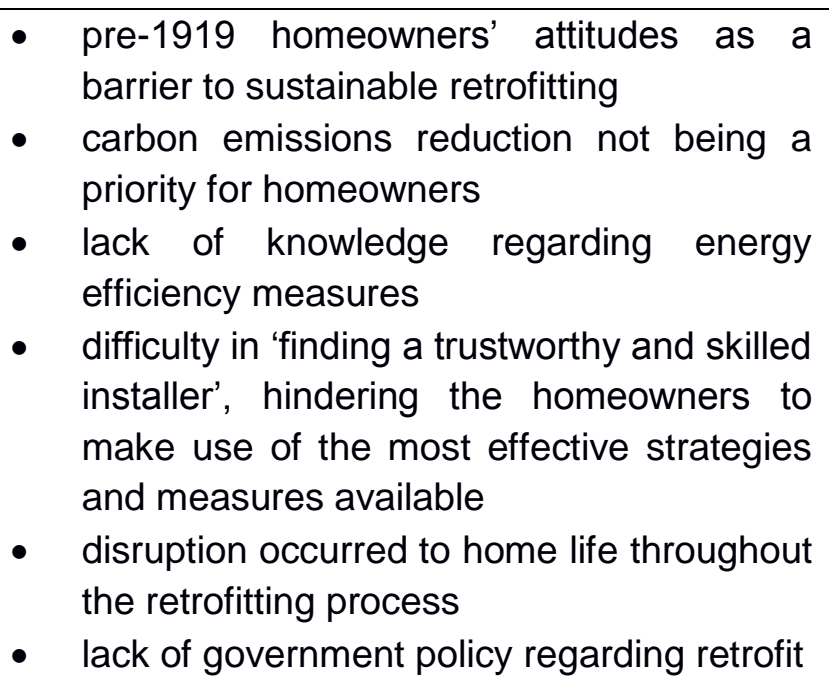 & $\begin{array}{l}\text { - } \text { Need for improving the home } \\
\text { comfort (health implications) } \\
\text { - Personal interest } \\
\text { - Aesthetic improvements in } \\
\text { the property }\end{array}$ \\
\hline Economic & $\begin{array}{l}\text { - } \text { restricted by funding for retrofitting } \\
\text { - challenging economic climate making it } \\
\text { unlikely that households will invest into } \\
\text { measures that are deemed as too } \\
\text { expensive, particularly for older pre-1919 } \\
\text { homes and have a long payback period } \\
\text { - difficulties in funding energy efficiency } \\
\text { improvements } \\
\text { - long payback period to repay on energy } \\
\text { efficient measures }\end{array}$ & $\begin{array}{l}\text { - financial gains and funding } \\
\text { - } \text { assistance including: } \\
\text { - } \text { reduced energy bills } \\
\text { - tax reduction } \\
\text { - the government grants } \\
\text { added property value }\end{array}$ \\
\hline Technical & 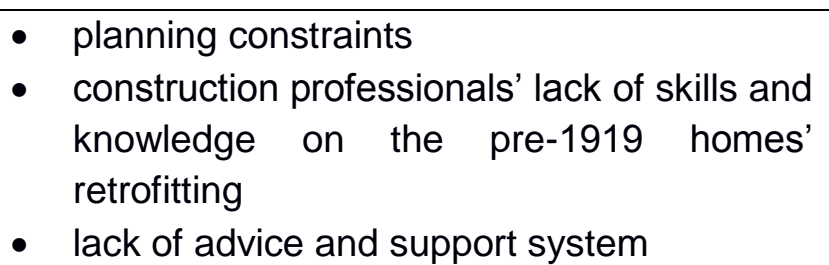 & \\
\hline
\end{tabular}

Greater awareness would present pre-1919 homeowners with a better knowledge of what can be achieved in older and inefficient property, making retrofit more viable. There is need for revised national and local policy to enable greater viability for retrofitting for implementation. It is essential that construction industry skills are improved through training and development to deliver a high quality pre-1919 retrofit. Capital funding assistance for homeowners through innovative funding models is a potential solution for increasing viability of retrofitting. For example, Energiesprong is a revolutionary, whole house refurbishment funding approach, originated in the Netherlands as a government-funded innovation programme. This funding model can be rolled out in UK homes.

This research has been constrained to some extent by difficulties in securing a larger sample size for the questionnaire survey and for interviews within homeowner and expert respondent samples. Future research can be conducted on a larger sample in the UK with more semi-structured interviews and questionnaire responses. Further research is also recommended on the impact of government policy 
on homeowners and the industry as well as on how to best address the financial barriers to retrofit homes. Considering the lack of economic viability, it is recommended that more needs to be done to address the affordability of retrofitting. For example the 'pay as you save' retrofit scheme adopted in Germany offers a potential solution for funding pre-1919 homeowners and should be considered for future research as an integrated strategy encompassing the benefits of retrofit/energy efficiency improvements in the UK (International Energy Agency, 2014).

\section{References}

Atkins, R., and Emmanuel, R. (2014). Could refurbishment of "traditional" buildings reduce carbon emissions? Built Environment Project and Asset Management, 4 (3), pp.221 - 237.

Baeli, M. (2013). Residential retrofit: 20 case studies. London: RIBA Publishing.

Banfill, P., Simpson, S., Haines, V and Mallaband, B. (2011). Energy-led retrofitting of solid wall dwellings - technical and user perspectives on airtightness. In: Ruddock, L. et al. (eds.) COBRA 2011

- Proceedings of the RICS Construction and Property Conference, 12th - 13th September 2011, University of Salford, Manchester, UK, pp.430-440.

Bernier, P., Fenner, R. and Ainger, C. (2010). Assessing the sustainability merits of retrofitting existing homes. Proceedings of the Institution of Civil Engineers: Engineering Sustainability, 163 (ES4), pp. 197-207.

Bhuiyan, S. I, Jones, K. and Wanigarathna, N. (2015). An approach to sustainable refurbishment of existing building In: Raidén, A. B. and Aboagye-Nimo, E. (Eds) Proceedings of the 31st Annual ARCOM Conference, 7-9 September 2015, Lincoln, UK, Association of Researchers in Construction Management, pp.1093-1102.

Boardman, B. (2007a). Home Truths: A Low-Carbon Strategy to Reduce UK Housing Emissions by $80 \%$ by 2050 . University of Oxford, Environmental Change Institute, Oxford, UK.

Boardman, B. (2007b). Examining the carbon agenda via the $40 \%$ House scenario. Building Research \& Information, 35, pp. 363-378.

Booth, A., and Choudhary, R. (2013). Decision making under uncertainty in the retrofit analysis of the UK housing stock: Implications for the Green Deal. Energy and Buildings, 64, pp. 292-308.

Bothwell, K., Saich, M. and Mallion, P. (2011). Retrofit of existing housing in the United Kingdom: the carbon reduction possibilities. Architecture and Sustainable Development, Proceedings of PLEA 2011, Louvain-la-Neuve, Belgium (July 2011).

BRE. (2014). The Government's Standard Assessment Procedure for Energy Rating of Dwellings, 2012 edition. Watford: Building Research Establishment. 
Britnell, J. and Dixon, T. (2011). Retrofit 2050 Working Paper: Retrofitting in the private residential and commercial property sectors - survey findings. Oxford: Oxford Brookes University.

Crilly, M., Lemon, M., Wright, A.J., Cook, M.B. and Shaw, D., (2012). Retrofitting homes for energy efficiency: an integrated approach to innovation in the low-carbon overhaul of UK social housing. Energy \& Environment, 23(6-7), pp.1027-1055.

Centre for Sustainable Energy (2011). Analysis of hard-to-treat housing in England, Internal research paper, Centre for Sustainable Energy, Bristol, UK.

CCC (2014). Meeting Carbon Budgets - 2014 Progress Report to Parliament: Chapter 3: Reducing emissions from buildings. London: Committee on Climate Change.

CCC (2015). Meeting Carbon Budgets -Progress in reducing the UK's emissions: 2015 Report to Parliament. London: Committee on Climate Change.

Department for Business, Energy and Industrial Strategy, (2017), Annual Fuel Poverty Statistics Report 2017, Department for Business, Energy \& Industrial Strategy, London, UK.

DCLG (2015a). English Housing Survey: Headline Report 2013-14. London: Department for Communities and Local Government.

DCLG (2015b). Energy Performance of Building Certificates: Statistics Release Q1 2008 to Q3 2015 England and Wales. London: Department for Communities and Local Government.

DECC (2013). Energy saving measures boost house prices [Online]. London: Department of Energy and Climate Change. Available at: https://www.gov.uk/government/news/energy-saving-measuresboost-house-prices [Last accessed 23/03/2016].

DECC (2015a). 2014 UK Greenhouse Gas Emissions, Provisional Figures: Statistical Release. London: Department of Energy and Climate Change.

DECC (2015b). Annual Fuel Poverty Statistics Report, 2015. London: Department of Energy and Climate Change.

Ding, G. (2013). Demolish or refurbish - Environmental benefits of housing conservation. Australasian Journal of Construction Economics and Building, 13, pp.18-34.

Dowson, M., Poole, A., Harrison, D., and Susman, G. (2012). Domestic UK retrofit challenge: Barriers, incentives and current performance leading into the Green Deal. Energy Policy, 50, pp.294-305.

Eames, M., Dixon, T., May, T. and Hunt, M. (2013). City futures: exploring urban retrofit and sustainable transitions. Building Research \& Information, 41 (5), pp.504-516.

Elsharkawy, H., and Rutherford, P. (2015). Retrofitting social housing in the UK: Home energy use and performance in a pre-Community Energy Saving Programme (CESP). Energy and Buildings, 88, pp. 25-33. 
Fawcett, T. (2014). Exploring the time dimension of low carbon retrofit: owner-occupied housing. Building Research \& Information, 42 (4), pp.477-488.

Galvin, R., and Sunikka-Blank, M. (2013). Economic viability in thermal retrofit policies: Learning from ten years of experience in Germany. Energy Policy, 54, pp.343-351.

Gillich, A. and Sunikka-Blank, M. (2013). Barriers to domestic energy efficiency - an evaluation of retrofit policies and market transformation strategies. Cambridge: University of Cambridge.

Gleeson, C., Yang, J., Lloyd-Jones, T. (2011). European Retrofit Network: Retrofitting Evaluation Methodology Report. London: University of Westminster.

Griffiths, W. (2010). SAP for Beginners: An introductory guide for building professionals. Watford: Building Research Establishment.

Guertler, P. (2011). Can the Green Deal be fair too? Exploring new possibilities for alleviating fuel poverty. Energy Policy, 49, pp. 91-97.

Hamilton, I.G., Steadman, P., Bruhns, H., Summerfield, A., and Lowe, R. (2013). Energy efficiency in the British housing stock: Energy demand and the Homes Energy Efficiency Database. Energy Policy, 60 , pp.462-480.

Hartless, R., and Standen, M. (2013). Greener Homes for Redbridge. Watford: Building Research Establishment.

HMSO (2008). Climate Change Act 2008. Norwich: Her Majesty's Stationary Office.

Ibn-Mohammed, T., Greenough, R., Taylor, S., Ozawa-Meida, L. and Acquaye, A. (2013). Operational vs. embodied emissions in buildings_-A review of current trends. Energy and Buildings, 66, pp.232245.

Iddon, C. R., and Firth, S. K. (2013). Embodied and operational energy for new-build housing: A case study of construction methods in the UK. Energy and Buildings, 67, pp.479-488.

International Energy Agency (2014). Capturing the Multiple Benefits of Energy Efficiency. International Energy Agency (IEA): Paris.

Jenkins, D.P. (2010). The value of retrofitting carbon-saving measures into fuel poor social housing. Energy Policy, 38, pp. 832-839.

Jones, P., Lannon, S., and Patterson, J. (2013). Retrofitting existing housing: how far, how much? Building Research \& Information, 41, pp. 532-550.

Lomas, K. J. (2010). Carbon reduction in existing buildings: a transdisciplinary approach. Building Research \& Information, 38 (1), pp.1-11. 
Long, T. B., Young, W., Webber, P., Gouldson, A., and Harwatt, H. (2015). The impact of domestic energy efficiency retrofit schemes on householder attitudes and behaviours. Journal of Environmental Planning and Management, 58 (10), pp.1853-1876.

MacKenzie, F., Pout, C., Shorrock, L., Matthews, A., and Henderson, J. (2010). Energy Efficiency In New And Existing Buildings: Comparative costs and $\mathrm{CO}_{2}$ savings. Watford: Building Research Establishment.

Malina, M. (2013). Delivering sustainable buildings: An industry insider's view. United Kingdom: WileyBlackwell.

Milsom, E. (2014). Solid wall heat losses and the potential for savings. Watford: Building Research Establishment.

Moorhouse, J., and Littlewood, J. (2013). The Evaluation of a palette of Low Carbon Measures applied to a Conservation Area Victorian Terraced House. Energy Procedia, 42, pp.597 - 606.

Moran, F., Blight, T., Natarajan, S. and Shea, A. (2014). The use of Passive House Planning Package to reduce energy use and $\mathrm{CO}_{2}$ emissions in historic dwellings. Energy and Buildings, 75, pp.216-227. NEF (2014). Breaking Barriers: An industry review of the barriers to Whole House Energy Efficiency Retrofit and the creation of an industry action plan. Summary Report, March 2014. National Energy Foundation [Online]. Available at: http://www.nef.org.uk/themes/site_themes/agile_records/images/uploads/BreakingBarriers_Summar yReport.pdf [Last accessed 06/12/2015]

Ofgem, 2016. Energy Company Obligation (ECO) [Online]. Available at https://www.ofgem.gov.uk/environmental-programmes/energy-company-obligation-eco [Last accessed 31/03/2016]

Palmer, J. and Cooper, I. (2013). United Kingdom housing energy fact file. London: Department of Energy and Climate Change.

Peacock, A. (2010) 22 - Materials for energy efficiency and thermal comfort in domestic buildings. Woodhead Publishing: Energy, pp.533-561.

Pelenur, M. J. and Cruickshank, H. J. (2014). Motivations to adopting energy efficiency measures in the home. Proceedings of the Institution of Civil Engineers: Energy, 167 (EN3), pp.103-116.

Pelenur, M.J. (2013). Retrofitting the domestic built environment: investigating household perspectives towards energy efficiency technologies and behaviour. Ph.D. thesis, University of Cambridge, Queens' College. 
Plimmer, F., Pottinger, G., Harris, S., Waters, M., and Pocock, Y. (2008). Knock it down or do it up? Sustainable house building: New build and refurbishment in the Sustainable Communities Plan. Watford: Building Research Establishment.

Power, A. (2008). Does demolition or refurbishment of old and inefficient homes help to increase our environmental, social and economic viability? Energy Policy, 36, pp.4487-4501.

Richardson, S., (2009). Morrell takes the stage with a warning to government. Building, 47, pp.10-11. Shorrock, L. (2003). A detailed analysis of the historical role of energy efficiency in reducing carbon emissions from the UK housing stock. Watford: Building Research Establishment.

Smith, L. (2015). Low Carbon Domestic Refurbishment in the UK Social Housing Sector: A Survey of Attitudes, Readiness and Adoption. M.Phil Thesis, University of Salford, School of Build Environment

Stafford, A., Gorse, C., and Shao, L. (2011). The Retrofit Challenge: Delivering Low Carbon Buildings. York: Centre for Low Carbon Futures.

Strube, J., Miller, A., and Ip, K. (2012). Solid wall insulation: its place in retrofit plans. Brighton: University of Brighton.

Sunikka-Blank, M. and Galvin, R. (2016). Irrational homeowners? How aesthetics and heritage values influence thermal retrofit decisions in the United Kingdom. Energy Research \& Social Science, 11, pp.97-108.

Thorpe, D. (2010). Sustainable home refurbishment: The Earthscan Expert Guide to Retrofitting Homes for Efficiency. $1^{\text {st }}$ edn. Washington, DC: Taylor \& Francis.

Tovar, M.A. (2012). The structure of energy efficiency investment in the UK households and its average monetary and environmental savings. Energy Policy 50, pp.723-735.

Technology Strategy Board (TSB) (2013). Scaling up retrofit of the nation's homes. London: Technology Strategy Board.

UKGBC (2013). Retrofit Incentives: Boosting take-up of energy efficiency measures in domestic properties. United Kingdom Green Building Council.

UKGBC (2015). Tackling embodied carbon in buildings. United Kingdom Green Building Council. UNFCCC (2014). Climate Change Information Sheet 17. United Nations Framework Convention on Climate Change [Online]. Available at: http://unfccc.int/essential_background/background_publications_htm/pdf/climate_change_informatio n_kit/items/300.php [Accessed 18/10/2015] 
Yates, T. (2006). Sustainable refurbishment of Victorian housing: Guidance, assessment method and case studies. Watford: Building Research Establishment. 